\title{
Law, Shared Activities, and Obligation
}

\section{Stefano Bertea}

\section{Introduction}

The contemporary debate in analytical legal philosophy is shaped by two truisms about law which jurisprudents have not yet managed to coherently work into a comprehensive theoretical framework. On the one hand, it seems to be a plain truth that the existence of law is essentially a matter of social facts, as is attested by the existence of legal systems that are recognized to function as such and yet have little or no moral worth and may even strike most people (including their addressees) as morally repugnant. On the other hand, only a handful of legal theorists are prepared to give up the claim that law presumptively provides its addressees with practical guidance and justification, thereby taking a normative stance by proffering distinctive reasons for action, while conferring rights and imposing obligations. Accommodating these two truisms about law is far from a straightforward exercise.

The main difficulty lies in the fact that neither can an institution's social existence in itself be a sufficient condition for the institution to have normative significance, nor can this normative significance be the main determinant of that social existence.

Therefore, contemporary legal philosophers find themselves stuck in what appears to be a dilemma with no obvious way out: insofar as they organise their accounts of law around law's social dimension, their legal theories run the risk of paying insufficient attention to the normativity of law, thus turning out an inaccurate explanation of such normativity; insofar as they instead put front and centre the law's capacity to generate reasons, rights, and obligations (at least presumptive ones), the sociality of law will tend to be neglected, and with it the significance of law's factual component.

This Janus-faced feature of law-its being at one and the same time a social practice and a normative institution-means that anyone seeking to put forward a comprehensive theory of law will have to reconcile two dimensions that seem to pull in opposite directions and yet are both recognised as fundamental and indispensable. So far this task has proved to be elusive for legal theorists. Non-positivists have gone a long way in accounting for the action-guiding and justificatory component of law. In their theories of law, the normative dimension of legal institutions is described with great accuracy, precision, and nuance. ${ }^{1}$ But their treatment of the social dimension of

I wish to express my indebtedness to Aldo Schiavello, Filippo Valente and the editors of the Canadian Journal of Law and Jurisprudence, who have offered helpful comments and critical remarks. Needless to say, the responsibility for the views expressed, as well as for any errors, rests solely with me.

${ }^{1}$ See generally, Lon L Fuller, The Morality of Law, revised ed (New Haven: Yale University Press, 1969); John Finnis, Natural Law and Natural Rights (Oxford: Oxford University Press, 1980); Michael J Detmold, The Unity of Law and Morality (London: Routledge \& Kegan Paul, 1984); Deryck Beyleveld \& Roger Brownsword, Law as a Moral Judgement (London: Sweet and Maxwell, 1986); Ronald Dworkin, 
law is far less detailed and sophisticated. As a result, one is left with the impression that non-positivism has little, if anything, original or useful to say about the sociality of law. In contrast, legal positivists have explained in great depth the social existence of legal systems-witness HLA Hart's rule-centred jurisprudence; Joseph Raz's exclusive legal positivism; the variants of legal conventionalism theorised by Gerald Postema and Andrei Marmor, among others; and the conceptualisation of law as an activity jointly engaged in by individuals acting as a community, a view paradigmatically championed, for instance, by Jules Coleman, Christopher Kutz, and Scott Shapiro. ${ }^{2}$ Yet it is still unclear how legal positivism can make full sense of the

Law's Empire (Cambridge: Harvard University Press, 1986); Ronald Dworkin, Justice in Robes (Cambridge: Harvard University Press, 2006); Ronald Dworkin, Justice for Hedgehogs (Cambridge: Harvard University Press, 2011); Michael S Moore, "Law as a Functional Kind" in Robert P George, ed, Natural Law Theory: Contemporary Essays (Oxford: Oxford University Press, 1992) 188; Michael S Moore, "Law as Justice" (2001) 18:1 Soc-\& Pol'y 115; Nicos Stavropoulos, Objectivity in Law (Oxford: Oxford University Press, 1996); Robert Alexy, "My Philosophy of Law: The Institutionalisation of Reason" in LJ Wintgens, ed, The Law in Philosophical Perspective (Dordrecht: Kluwer, 1999) 23; Robert Alexy, "The Special Case Thesis" (1999) 12:4 Ratio Juris 374; Robert Alexy, "On the Thesis of a Necessary Connection between Law and Morality: Bulygin's Critique" (2000) 13:2 Ratio Juris 138; Robert Alexy, The Argument from Injustice: A Reply to Legal Positivism, translated by Stanley L Paulson \& Bonnie L Paulson (Oxford: Oxford University Press, 2002); Mark C Murphy, "Natural Law Jurisprudence" (2003) 9:4 Legal Theory 241; Mark C Murphy, Natural Law in Jurisprudence and Politics (New York: Cambridge University Press, 2006); Mark Greenberg, "How Facts Make Law" (2004) 10:3 Legal Theory 157; Mark Greenberg, "Hartian Positivism and Normative Facts: How Facts Make Law II" in Scott Hershovitz, ed, Exploring Law's Empire:The Jurisprudence of Ronald Dworkin (Oxford: Oxford University Press, 2006) 265; Nigel Simmonds, Law as a Moral Idea (Oxford: Oxford University Press, 2008). ${ }^{2}$ See HLA Hart, Concept of Law, with Postscript, 2d ed by Penelope A Bulloch \& Joseph Raz (Oxford: Oxford University Press, 1994); Joseph Raz, The Concept of a Legal System: An Introduction to the Theory of Legal System (Oxford: Clarendon Press, 1970); Joseph Raz, Practical Reason and Norms (London: Hutchinson \& Company,1975); Joseph Raz, The Authority of Law: Essays on Law and Morality (Oxford: Oxford University Press, 1979); Joseph Raz, "Hart on Moral Rights and Legal Duties" (1984) 4 Oxford JLegal Stud 123 [Raz, "Hart”]; Joseph Raz, The Morality of Freedom (Oxford: Oxford University Press, 1986); Joseph Raz, Ethics in the Public Domain: Essays in the Morality of Law and Politics (Oxford: Clarendon Press, 1994) Raz, Ethics; Joseph Raz, "Incorporation by Law" (2004) 10:1 Legal Theory 1; Gerald J Postema, "Coordination and Convention at the Foundations of Law" (1982) 11:1 J Legal Stud 165; Andrei Marmor, Interpretation and Legal Theory (Oxford: Clarendon Press, 1992); Andrei Marmor, Positive Law and Objective Values (Oxford: Oxford University Press, 2001) [Marmor, Values; Andrei Marmor, Social 
(presumptive) obligatoriness of legal institutions, while holding fast to the claim that the existence of law is exclusively a matter of social facts, a claim that, under the label of the 'social-fact thesis' contributes to defining legal positivism and differentiating it from non-positivist theories of law. ${ }^{3}$ As a result, the accuracy with which the social existence of law is explained by legal positivists has traditionally come at the price of offering an inchoate account of law's recognised ability to guide action by saying not just how we are expected to behave, in a social, or conventional, sense, but also why those expectations are justified, or why that behaviour ought to be engaged in as a matter of principle.

The difficulty legal positivism faces in accounting for the normative component of law does not just bedevil the traditional forms of this school of thought. Ever since the The Concept of Law, where Hart explicitly acknowledges how central to law are its action-guiding role and justificatory force, ${ }^{4}$ these two features of law have become a

Conventions: From Language to Law (Princeton: Princeton University Press, 2009) [Marmor, Conventions; Jules L Coleman, "Constraints on the Criteria of Legality" (2000) 6:2 Legal Theory 171 [Coleman, "Constraints"]; Jules L Coleman, "Incorporationism, Conventionality, and the Practical Difference Thesis" in Jules Coleman, ed, Hart's Postscript (Oxford: Oxford University Press, 2001) 99 [Coleman, "Incorporationism"]; Jules Coleman, The Practice of Principle (Oxford: Oxford University Press, 2001) [Coleman, Practice; Scott J Shapiro, "Law, Plans, and Practical Reason" (2002) 8:4 Legal Theory 387 [Shapiro, "Reason”]; Scott J Shapiro, Legality (Cambridge: Cambridge University Press, 2011) [Shapiro, Legality; Scott Shapiro, "Massively Shared Agency" in M Vargas \& G Yaffe, eds, Rational and Social Agency: Essays on the Philosophy of Michael Bratman (Oxford: Oxford University Press, forthcoming); Christopher Kutz, “Acting Together" (2000) 61:1 Phil \& Phenom Research 1 [Kutz, "Together"]; Christopher Kutz, "The Judicial Community" (2001) 11 Phil Issues 442 [Kutz, "Community"].

${ }^{3}$ The reason why legal positivism finds it difficult to explain legal obligation can be framed in terms of the is-ought gap. Indeed, the moment we construct law as being essentially a matter of social facts, we are in the realm of the 'is', whereas obligations are prescriptive and so belong with the 'ought'. Therefore, if on these premises (i.e., law as fact) law is claimed to give rise to obligations, a transition will have been effected from 'is' to 'ought'. But this is precisely the sort of transition that legal positivism would deem illicit, for it would amount to bridging what--under the view known as Hume's law--is not amenable to bridging.

${ }^{4}$ See supra note 2 at 82-91. Hart proceeds on the basis of these two components (coupled with a few other arguments) to show the inadequacy of John Austin's command theory of law. Hart argues that, although the theory is constitutively unable to explain how law can guide us in general, it can do so specifically by generating obligations to act in the prescribed way, as opposed to obliging (i.e., forcing) one to do so. For a recent restatement of the thesis of the action-guiding dimension of law, see Coleman, "Incorporationism", supra note 2 and Coleman, Practice, supra note 2 at 67-73, 134-48; Shapiro, Legality, supra note 2 at 113-15. 
major concern in the Anglo-American debate in jurisprudence, and contemporary positivists have systematically dealt with law's ability to provide justifying reasons for action (reasons that justify and yet are distinctively legal) and to give rise to presumptive obligations. Yet even the subtlest and most polished versions of contemporary legal positivism explain legal normativity and obligation in ways that range from incomplete to incoherent with the basic tenets of positivism itself. I will attempt to illustrate this with respect to a variant of legal positivism that has increasingly gained ground in recent years: the view of law as an activity shared by a given community of individuals, or, stated otherwise, as a peculiar and distinctive form of 'acting together'.

This view I will henceforth refer to under the label 'law as a shared activity'. I hope to contribute to a critical assessment of the way the conception of law as a shared activity explains the normative component of law in general and legal obligation in particular. So the question will be: can law as a shared activity provide a thorough account of the quality and scope of legal obligation, and can it in this wayas a form of legal positivism-adequately explain law's ability to impose prima facie obligations?

The discussion is set up as follows. I will first introduce the conception of law as a shared activity and reconstruct it as a general account of law and its normativity (Section 2). Then I will turn specifically to the conception's account of legal obligation (Section 3), which is rendered by giving it two fundamental senses: a fullblooded sense and a perspectival one. The rest of the discussion will be devoted to showing why, the account is flawed in both of these senses. Thus (in Section 4) I will argue that the account of legal obligation in a full-blooded sense is at once too limiting and partial. For it can explain legal obligation only in relation to those who are already committed to the legal enterprise, so we are left to wonder why everyone else should also have an obligation to comply with the law, or how obligation can have such broad scope under the law. Furthermore, we are not presented with a compelling argument that the obligations the law gives rise to are non-moral obligations grounded in social facts (or that they are distinctively legal obligations), even though it is precisely this sort of argument that legal positivism needs to make after Hart. Finally (in Section 5) I turn to the perspectival sense of legal obligation, arguing that this rendering of obligation overlooks the practical import the legal enterprise is widely acknowledged to have, thus failing to explain the ability of legal institutions to play their typical guidance function through the obligations they set forth.

\section{The Conception of Law as a Shared Activity}

Every day we each carry out many acts: some of these we carry out individually, but some we carry out in concert with others, whose activities either provide the conditions for our own, or form the background to our own, or constitute specific components of our own. In all cases where our action is not individual, that is, in all cases of shared activity, the activities of others are indispensable to our own, in that 
what we do is either impossible or meaningless in isolation from what other people do. Therein lies the basic idea of law as a shared activity. This is a twofold idea: it consists in (a) describing law as a practice jointly undertaken by a group of individuals, each of whom contributes in a distinct way to the collective undertaking; and (b) observing that this practice (or the legal system it props up) cannot-without distortion-be interpreted as the outcome of the activities of a collection of individuals each acting separately because legal practice results from the concerted action of a collectivity and is thus best interpreted as a paradigmatic case of a group 'acting together'. Legal actors should be regarded as participants in a joint project, namely, individuals who have certain ends and a participatory intent in common. In sum, law originates within an activity resulting from the actions and interactions of individuals sharing a participatory intent.

Those who espouse the idea that we should conceive of law as a special kind of shared activity give legal specificity to it in different ways. But before we get into the differences, I will first lay out the features that these different variants have in common. This can serve as a useful introduction, not least because the conception has not yet received any systematic treatment.

The conception of law as a shared activity, it was earlier mentioned, is a form of legal positivism developed as an attempt to deal with some core issues that Hart first identified, which have since become central to the Anglo-American debate. It will therefore be useful to bring this conception into contrast with the other main strand of post-Hartian legal positivism defended in analytical jurisprudence today, namely, legal conventionalism. For a long time now, the argument has been that legal conventionalism is what analytical legal positivism essentially comes down to, and that the two approaches can in this sense be identified. As Coleman once put it, contemporary legal positivism 'is committed to explaining law as ultimately resting on social convention' and hence committed to the view that the conditions for the existence of law are established by convention. ${ }^{5}$ The conception of law as a shared activity, by contrast, does not regard conventionalism as a necessary element of a legal-positivist account of law. ${ }^{6}$ On this view, joint action serves as the fundamental

\footnotetext{
${ }^{5}$ See "Incorporationism", supra note 2 at 103 and n 9; Coleman, Practice, supra note 2 at 68 . This claim goes under the name of the conventionality thesis, a thesis defended by contemporary analytical legal positivism and stating that the criteria of legality are conventional. The connection between legal conventionalism and legal positivism finds a thorough theorisation in Marmor, Values, supra note 2 at 1-48; Andrei Marmor, "How Law is Like Chess" (2006) 12:4 Legal Theory 347; Marmor, Conventions, supra note 2; Andrei Marmor, Philosophy of Law (Princeton: Princeton University Press, 2011) at 35-83; Jose Vilajosana, El derecho en acción (Madrid: Marcial Pons, 2010). For a critique of this connection, see Leslie Green, "Authority and Convention" (1985) 35:141 Phil Quarterly 329; Leslie Green, "Positivism and Conventionalism" (1999) 12 Can JL \& Jur 35.

${ }^{6}$ See Kutz, "Community", supra note 2 at 453-55. This gives that conception an edge over other versions of legal positivism, especially in view of the problems by which
} 
legal criterion, the one that (directly or indirectly) determines what counts as law, or the element lacking which something cannot be said to count as law. That is something is law to the extent that, necessarily, it can be described as a collective practice consisting in a group acting together and sharing a goal. Since those who act together may, but need not, do so on the belief that this is required by, and is in accordance with, a social convention, the resulting practice is not necessarily conventional in character. So, what distinguishes further a joint action or shared activity, which on this conception figures as the basic criterion of legality, is that this activity may be social but need not be conventional. ${ }^{7}$

This conception of the legal enterprise owes much to a body of work on the theory of action where the effort has been to understand the dynamics characterising interpersonal interaction and collective action. A connection can thus be established between the conception of law as a shared activity and contemporary studies in the philosophy of social action. Looming large among these studies is Michael Bratman's theory of social action. To a large extent, then, the conception of law as a shared activity (such as it has so far been theorised) can be interpreted as an attempt to extend Bratman's specific account of shared intentional activity to the study of law. ${ }^{8}$ This means that law is specifically defined in terms of an activity engaged in by individuals who (a) are mutually responsive to the intentions and actions of others, (b) are committed to the joint activity, (c) share the plans (and sub-plans) instrumental to performing the relevant joint action, and (d) are aware that others intend to act jointly in the relevant way, and thus expect these other participants to contribute to the common activity. On this conception, those who take part in a collective practice need

legal conventionalism is plagued. For a recent statement of these problems, see Christian Dalhman, "When Conventionalism Goes Too Far" (2011) 24:3 Ratio Juris 335. For a conventionalist reading of the conception of law as a shared activity, see Coleman, Practice, supra note 2 at 74-102.

${ }^{7}$ See also Michael Bratman, "'Shapiro on Legal Positivism and Jointly Intentional Activity" (2002) 8:4 Legal Theory 511 at 515-16.

${ }^{8}$ Not everything that falls under the umbrella of the conception of law as a shared activity bears a connection to Bratman's model of shared intentional action. As we will see in the final part of this section, Kutz frames the conception of law as a shared activity by reference to an account of joint or collective action that clearly departs from Bratman's. Although these two accounts go in opposite directions, they are both individualistic: they reject the claim that doing something together implies the emergence of a supra-agential entity. More to the point, even though what we do together is more than the sum of our individual activities, and so cannot be reduced to those activities, the resulting joint action can be explained solely by reference to the single coagents' intentional and cognitive states, and so does not make it necessary to introduce a supervenient plural subjectivity. For a non-individualist approach to shared activities, see Margaret Gilbert, Theory of Political Obligation (Oxford: Clarendon Press, 2006). 
share only certain goals and plans: they are not required to have the same reasons for participating in it. Shared activities depend on our capacity to have certain objectives in common, even though the reasons we each have for pursuing those objectives may not coincide or even overlap.

In bringing this account of shared activities to bear on law, however, the advocates have not simply reproduced and contextualised the insights originally theorised in the philosophy of social action: they have expanded on, and partly modified, them. What makes it necessary to tweak these insights and revise the account is essentially the different subject matter to which they apply. Whereas the model case for the investigation of joint action involves personal interaction among small groups in the absence of authority, neither of these two elements describe legal practice. Legal practice (a) does not depend on the ability of individuals to interact face to face as members of small groups, and (b) involves activities carried out under the regulation of an authority. To draw on the philosophy of social action, the conception of law as a shared activity requires a new model case.

In this reconstructive process, the conception of law as a shared activity has been shaped in a variety of ways, with different interpretations of what social philosophers take to be the core elements of joint action. What all these accounts of law as a shared activity have in common is the idea of law as a distinctive mode of 'acting together', an idea that frames the legal domain as a social practice jointly engaged in by certain individuals. They take different paths in the way they construct the collective undertaking understood to uniquely characterise law. And herein contemporary analytical jurisprudence, among those who defend the conception of law as a shared activity we find two broad groups: those who offer a 'thicker' account of this collective undertaking and those who instead offer a 'thinner' account.

\subsection{The Thicker Account}

In the first camp we find Jules Coleman, who construes the conception of law as a shared activity in a theoretically robust and demanding way. ${ }^{9}$ Coleman initially put forward a positivist account of legal activity understood as a coordination convention, but then, having come to the realisation that coordination conventions can go only so far in explaining the law, he turned to what Bratman calls a shared cooperative activity. This is where Coleman's theory reveals its robustness, because unlike Shapiro and Kutz, who define law only in terms of a shared intentional activity, Coleman views this activity as cooperative. This means that those who participate in and shape the legal practice are understood to have a commitment to mutually support one another's effort to do their share in the legal system. ${ }^{10}$ Even more specifically,

\footnotetext{
${ }^{9}$ See especially Coleman, "Incorporationism", supra note 2 at 114-21; Coleman, Practice, supra note 2 at 74-102.

${ }^{10}$ This is in addition to their having a shared participatory intent. So we have an added layer of commitment here: the participants' shared intent is also a commitment to cooperate in making the joint activity a viable enterprise.
} 
however, Coleman considers that the participants in question are the legal officials. That is because Coleman, following Hart, looks to the rule of recognition as an essential legal practice in explaining the nature of law: the rule of recognition is the official practice through which the criteria of validity are established, determining what counts as law in any given jurisdiction. Since this practice, in Coleman's view, is best understood as a Bratmanian shared cooperative activity among legal officials, it follows that at the core of any system of laws there is a practice-the rule of recognition-that takes the distinctive form of a cooperative activity jointly carried out by legal officials. Stated otherwise, a legal system is best understood as the outcome of a citizen addressed project shared and pursued cooperatively by a specific group of individuals-legal officials.

Another scholar who relies heavily on Bratman's theory in shaping the conception of law as a shared activity is Scott Shapiro, who in a recent work has defended an original account of law significantly revising the positivist stance from within. What sets Shapiro's theory of law apart from other positivist theories is that Shapiro regards legal activity as a distinctive form of shared activity: a form of social planning accordingly called the 'planning thesis'. As an instantiation of the activity of social planning, law is understood to embody what might be called 'massively shared agency with authority'. ${ }^{11}$ This idea of massively shared agency with authority draws on Bratman's model of shared agency but makes some deep changes to it. In Shapiro's view, insightful though Bratman's model may be in several respects, it cannot be applied to legal institutions straightaway, for it does not as such recognise the role that impersonal authorities play in the governance of social affairs. Only when it is made to recognize that role can it be used to shed light on the nature and mechanisms of legal systems. In this way, shared agency can be said to hold even when some agents in the group stand in a relationship of superiority to the others and even when not everyone in the group is committed to the joint enterprise. In addition, on Shapiro's revised model, coercion is not an obstacle for a group of individuals jointly performing an activity, at least not to the extent that coercion is used as a backup strategy to promote general conformism. ${ }^{12}$

Shapiro proceeds from the notion of massively shared agency with authority and sets out his 'planning theory of law' by construing law as a kind of collective planning activity. ${ }^{13}$ This activity (the law) is described by him as 'an incremental process whose function is to guide, organize, and monitor behaviour through the settling of normative questions and which disposes its addressees to comply under normal conditions'. ${ }^{14}$ In this conceptual framework the law is a large-scale, hierarchically structured activity carried out by those entrusted with planning for the wider community (the legal officials). The planning theory reconstructs legal systems as institutions of social planning, legal rules as plans or plan-like norms, and,

\footnotetext{
${ }^{11}$ Shapiro, Legality, supra note 2 at 195

${ }^{12}$ See ibid at 161-73.

${ }^{13}$ For a summary statement of this legal theory, see ibid at 193-233.

${ }^{14}$ Ibid at 203.
} 
consequently, legal officials as planners. By creating, implementing, and enforcing social plans, legal officials guide the behaviour of individuals and groups, thus helping them 'lower their deliberation, negotiation, and bargaining costs, increase predictability of behaviour, compensate for ignorance and bad character, and provide methods of accountability'. ${ }^{15}$

What makes the planning theory a positivist theory of law is that the plans are mere social facts, rather than as morally driven arrangements. They may have a moral component, but that is not what makes them operative. Their active existence is owed not to any moral worth they may claim or embody, but to their de facto acceptance, meaning that, having been designed, they are made publicly accessible and gain acceptance within a social group. If the effective currency and content of social plans is not essentially dependent on moral considerations, and if law consists in the activity of social planning, then the existence and authority of law can be said to be exclusively a matter of social facts, which is precisely the legal-positivist argument.

\subsection{The Thinner Account}

An alternative, 'thinner' version of the conception of law as a shared activity can be found in the work of Christopher Kutz, who significantly weakens the conditions by which a collective practice is defined in law. Kutz looks at how Coleman and Shapiro adjusted Bratman's conditions of a collective practice to the legal context but finds that this and other existing models of joint action theorised by social philosophers are too metaphysically and psychologically demanding. Hence the minimalist conception of collective action he introduces to correct these flaws. ${ }^{16}$ On this minimalist conception, collective action takes place whenever individuals as a group organise their conduct around a common project in which they share a participatory intention. Participatory intention is an attitude or disposition held when contributing to a broader project: a willingness to promote the aims and activities shared by the whole group, not those of any one individual in isolation from the others. ${ }^{17}$

What makes this a stripped-down notion of acting together is that the participatory intention it is defined by requires neither a belief that people are disposed to act in certain ways, nor a belief that they are motivated by an attitude of responsiveness to others, nor does it require any special relationships of mutual interdependence in the manner Bratman proposes. This stands in contrast to Coleman and Shapiro in two respects. First, Coleman and Shapiro rely on Bratman's model of shared agency. Second, the legal theories of Coleman and Shapiro (however much they may diverge

\footnotetext{
${ }^{15}$ Ibid at 200.

${ }^{16}$ The same minimalist strategy has been explored in Rodrigo Sanchez Brigido, "Collective Intentional Activities and the Law" (2009) 29:2 Oxford J Legal Stud 309 (Brigido defends a model of joint action, which can be considered coherent with the spirit of Kutz's overall project despite a partial divergence).

${ }^{17}$ See Kutz, "Together" supra note 2 at 4-10.
} 
in other respects) take on a set of ontological features and psychological preconditions that commit us to specific views of what it means to act together, which-makes Coleman's and Shapiro's conceptions of joint action special (and more demanding) cases in comparison with Kutz's more basic and paradigmatic idea. This renders Kutz's reduced model more inclusive since it expands the notion of acting together so as to bring within its scope situations where individuals in a group (a) can still be regarded as engaging in joint action despite the fact that they do not necessarily relate to one another on an equal footing, (b) may be alienated from the overall enterprise they contribute to, and (c) work toward a vaguely specified purpose without even knowing who the other participants in the project are.

Kutz frames his conception of collective action in a minimal and hence comprehensive way, so as to encompass within this idea that of the legal system as such a form of activity. More to the point, Kutz views law as the activity engaged in by a group of individuals who each intentionally do their share in a common project of establishing the criteria of legality and in using this as a basis on which to regulate social interaction, settle possible disputes, and enforce decisions. The individuals involved in this specific kind of collective activity (the kind we call law) are a given system's legal officials-or 'law-determiners' in Kutz's lexicon-prominent among whom are the judges. ${ }^{18}$ A legal system is thus defined by Kutz as 'a set of judges, each intentionally contributing to the systematic distinction of legal from non-legal norms and regulating their application, plus other institutions capable of generating and enforcing those norms'. 19

\section{Legal Obligation}

On the conception of law as a shared activity, legal obligation is explained as part of a broader account of the normative dimension of law. The account is framed in positivist terms; so the challenge is to explain legal obligation consistently with the fundamental positivist tenet, the social-fact thesis.

There are two ways in which this challenge has been addressed by those who champion the conception of law as a shared activity. First, there is the view of legal obligation in a full-blooded sense, as a rational requirement associated with the existence of legal institutions, activities, or provisions. Second, there is the perspectival view of legal obligation as a demand arising in a situation where one is asked to do something from a given point of view, namely, that of the legal enterprise itself. These two senses of legal obligation may look quite similar, but because the difference between them is substantive not cosmetic, I will devote this section to showing in what way this is so.

What legal obligation in the full-blooded sense has in common with legal obligation in the perspectival sense is its originating not from any moral or metaphysical principle per se but from that specific form of shared practice which (on

\footnotetext{
${ }^{18}$ See Kutz, "Community", supra note at 443.

${ }^{19}$ Ibid at 461.
} 
the conception of law as a shared activity) is where we must locate the legal phenomena. But this is as far as the comparison will go, because in the full-blooded sense, legal obligation gives rise to a genuinely practical demand, in a way that legal obligation in a perspectival sense does not. Legal obligation in a full-blooded sense stands for a requirement that competes with general practical reasons and so figures in a determination of what one ought to do generally, vis-à-vis what one ought to do in accordance with the law-law, which is, in turn, understood as a discrete domain set apart and disconnected from the practical domain (the domain of agency and action). So, in the full-blooded sense, legal obligation is a practically rational requirement: the reasons offered by law affect our practical life and choices in general. More to the point, as much as legal obligation may have its source in a system of laws, it cannot fully be explained solely by reference to that system, because legal systems either make explicit or reinforce or generate anew requirements we ought to at least prima facie recognize independently of their being legal. These requirements are thus at least partly independent of the legal sphere, and to that extent they can be considered genuine requirements, namely, practically rational requirements .

How this comes about has been explained in a comprehensive way by Coleman, so it is to his account that we will turn for a better understanding of the full-blooded sense of legal obligation. ${ }^{20}$ Coleman relies on Bratman's theory of shared cooperative activity to explain not just the existence of law-law exists insofar as a certain group of individuals engages in such an activity-but also the mechanism through which the legal system so conceived can give rise to genuine obligations. The basic premise is that the shared activity in which law is explained is a network of interacting agents whose individual activity depends on there being some form and degree of cooperation. This is a shared cooperative activity (this is the structure of the rule of recognition we use as a benchmark by which to separate law from non-law), and the people who engage in it (in this network of relations) come to depend on one another for a range of vital activities that would not otherwise be possible if they were not so networked and cooperative. Ergo, each participant in this network has a legitimate expectation that everyone will do one's part or fulfill some role in the cooperative scheme which is the shared activity itself, for otherwise the enterprise would break down. This expectation gives rise to an obligation to act accordingly-or rather, it gives rise to a set of mutual obligations the participants each owe to one another. This can be considered a genuine, or practically rational, obligation because, although it does originate from that shared activity which is the law, there is nothing specifically or exclusively 'legal' about it. It can be explained by invoking the structure of an enterprise (a shared cooperative activity) without introducing any distinctly legal terms or principles.

\footnotetext{
${ }^{20}$ See generally Practice, supra note 2 at 86-102, 143-217. The account no longer reflects Coleman's view but since there is no competing account that is as thorough in explaining what full-blooded legal obligation is on the conception of law as a shared activity, I will take Coleman's view as paradigmatic in that respect.
} 
An essential ingredient in this construction (serving to complete the explanation) is that of endorsement. In Coleman's theory, the shared cooperative activity to which the rule of recognition owes its structure is not just a pattern of behaviour that people in the group at hand happen to conform to, but rather a practice they are committed to because they recognize that it involves a mutual interdependence which must involve a renunciation of free-riding. Crucially, an endorsed practice is one that generates reasons for its participants to act in accordance with the prescriptions arising out of the practice itself. Since these reasons entail corresponding obligations (at least in part or occasionally), then to the extent that law can be defined in terms of a shared cooperative practice, we can explain its capacity to generate genuine obligations for the social group engaged in that practice.

The key to this account lies in its specification of the source and nature of a reason for action, because a reason so conceived will be taken as the basis for an obligation to act accordingly. Reasons for action, as we have seen, are understood on this account to arise out of a cooperative practice, and it is to this source that they owe their validity and practical relevance. However, what makes them valid and relevant is not their content (i.e., the particular ethos or substantive values a given cooperative practice happens to embody) but the cooperative nature of that practice, that is, its formal structure as a network of interdependent individuals mutually committed to the enterprise itself. This explains three features of a reason for action in the context of a shared practice. First, these reasons are content-independent (in the sense just explained that they do not owe their status to the content of the conduct they call for). Second, they are peremptory, in that they bar any independent deliberation and argument, preventing their addressees from critically questioning the worth of engaging in the required behaviour (this, too, is a feature deriving from the nature of the practice as an enterprise whose survival is predicated not on the content of its mores but on the nature of its form as a network of cooperative and hence mutually interdependent activities). Third, reasons for action-in the context of that cooperative practice which is the law-are genuine, meaning that even though they are distinctly legal, and so cannot be reduced to moral reasons, they work just like moral reasons and se enter into competition with them. As Coleman puts it, these reasons, along with the associated obligations, 'are not tied to the institution of law in the way, for example, many of rights and duties created by the rules of a game are ... . Legal duties arise in law, but they are duties that figure in our determination of what we ought to do generally and not just in our deliberations about what we ought to do in playing the game "law". ${ }^{21}$ In other words, if on the one hand the reasons for action and the obligations generated by law are in virtue of that fact specifically legal, on the other hand they are grounded in a broad enough way that they also enjoy an extended practical relevance (a sense in which they can be said to compete with non-legal practical demands, including moral ones).

This last feature captures the sense in which this account of legal obligation can be described as full-blooded. Legal obligation is understood as making a genuine claim

\footnotetext{
${ }^{21}$ Practice, supra note 2 at 143.
} 
on us as practical agents (one might also call this a 'rational' claim), and legal obligation can do so because of the way in which (on this account) it is extracted out of the law as a cooperative scheme and practice we commit to. This means that, while legal obligation (as the adjective suggests) is distinctly legal-for it originates in lawit is not on account of law qua law but on account of law qua shared practice. This makes it possible for legal obligation to transcend law (and move into the realm of the practical at large) while retaining a specifically legal core that makes it irreducible to rational (and moral) obligation at large.

The account is positivist because the shared practice in which the law is constituted is not just an inert practice (something that happens to take place) but one in which the participants commit or endorse. The practice would make no sense but for the fact that we endorse it, so it essentially relies on our social acceptance of it. The account is full-blooded because the fact of social acceptance is understood to give rise (among participants) to an obligation at once legal and grounded in a principle broader than the law: the principle under which mutual commitment to a shared practice that everyone is dependent on entails a rational requirement to live up to the expectations such commitment gives rise to.

Both of these features-the genuine quality of legal obligation and its being grounded in social facts-can be used to contrast the full-blooded account of legal obligation with the perspectival account. To this end we go back to Shapiro and his theory of law as a form of social planning because this theory gives us not one but two accounts of social obligation: one which applies to agents in their capacity as legal officials (the people engaged in the activity of social planning) and the other which applies to agents in their role as ordinary citizens. This distinction is significant because while legal obligation as it applies to agents in the former group can be described as full-blooded, it cannot be so described in relation to agents in the latter group (and it is here that obligation in a perspectival sense comes into play).

Let us start from the activity of social planning in relation to legal officials. On Shapiro's account, there are two reasons why legal officials can be said to have obligations under the law. The first is rooted in their commitment to the master plan lying at the foundation of law (and this is the social fact of acceptance). The second is rooted in the principle of instrumental rationality and coherence under which an agent ought to act consistently with past resolutions, for otherwise that agent can be criticized either as irrational (resolving to do something only to subsequently proceed along a course that contradicts that choice) or at least as inconsistent, disregarding the very plan one has had a part in designing in an official capacity or has otherwise accepted. As Shapiro puts it, if a 'subject has accepted the shared plan' then 'from the point of view of instrumental rationality, he is bound to heed the plan' ${ }^{22}$ For this reason 'legal officials are rationally required to conform to their shared plan'. ${ }^{23}$ These two reasons combine to give rise to a presumptive genuine obligation of legal officials to do what the law requires. This obligation can be construed as genuine because it

\footnotetext{
${ }^{22}$ Legality, supra note 2 at 142.

${ }^{23}$ Ibid at 182 .
} 
arises out of the law (and is thus distinctly legal) and yet it also finds a rational basis in the moral principles behind acceptance and commitment.

But now we ask, what about those who have no part in framing the shared plans constitutive of law or who do not endorse these plans? As Shapiro argues, 'those who do not accept the law are not similarly bound'. ${ }^{24}$ We cannot apply to them the same argument we applied to legal officials, so it can be presumed that there is no practically rational basis on which to claim that they are bound by law. But a legal obligation need not be rationally grounded in that way: it can also be understood in a perspectival sense. In this perspectival sense (the second important sense in which the conception of law as a shared activity understands legal obligation, what it is to have a legal obligation is not to be bound by any broad principle of practical rationality, but only to be bound from a legal point of view, from the standpoint of one who merely acknowledges the legal system rather than fully committing to it. ${ }^{25}$ A legal obligation in this perspectival sense-the sense arising from the standpoint of one embedded in the context of the legal system and who takes the distinctive perspective of the master plan forming the foundation of law-is not an obligation in a genuine sense, because it stands only so long as we wall off any (practical moral) considerations not specific to the shared practice or master plan itself. ${ }^{26}$ An obligation so constructed comes down to the rather prosaic-sounding statement, 'You are in this practice, so you are expected to behave in the manner that everyone else does who is similarly situated'.

This is why legal obligation in this perspectival sense is less demanding than legal obligation in the full-blooded sense. The two understandings of legal obligation share the social fact of people being situated in a given shared practice legal obligation in a perspectival sense applies regardless of whether one is a legal official). Where they depart is in the kind of commitment they require. Legal obligation in a full-blooded sense requires individuals to have an active role in shaping the relevant practice and to endorse its form of life. This makes it a genuine obligation consequent on what it means to accept a shared practice to which others are also committed. By contrast, legal obligation in a perspectival sense requires not so much a commitment as an understanding of what is expected of one who happens to be embedded in the context of a given practice framed by a specific set of rules. This makes it a context-specific obligation having no authentically moral foundation, that is, no foundation outside that specific practice.

\section{Full-Blooded Legal Obligation}

\footnotetext{
${ }^{24}$ Ibid.

${ }^{25}$ The idea can be framed on a language-analysis approach by saying that the term 'legal' modifies not 'obligation' (in the noun phrase 'legal obligation') but the whole embedding statement 'So-and-so has a legal obligation'.

${ }^{26}$ The point that legal obligation in a perspectival sense is not a genuine obligation is also made in Kutz, "Community", supra note 2 at 463-65.
} 
In this section and the next, I will discuss in turn the two different senses of legal obligation just introduced, engaging critically with each account so as to assess whether it is (a) adequate, by which I mean exhaustive, and (b) coherent with the basic tenets of legal positivism (those that set it apart from non-positivism).

So let us proceed to the full-blooded account, regarding which a preliminary remark is in order. A distinction is needed to clarify the kind of legal obligation, or ought, the account is attempting to explain. On the one hand, as concerns the ought, there is the familiar question about whether we ought to follow the rules of law or the validly enacted legal provisions that apply to any legal subject, regardless of the reason why that person is to be considered a subject of law. This we might call 'legal obligation as formal compliance'. On the other hand, there is the broader question as to whether we ought to join that shared activity to begin with, that is, whether we even have an obligation to participate in the shared project instantiating the legal systemunder which we are presumptively subject to an obligation in the former sense of formal compliance. Obligation in this broader sense (call it 'participative obligation') is a question the conception of law as a shared activity does not deal with at length. So it is only an account of obligation as formal compliance that the conception of law as a shared activity seeks to explain.

Participative obligation in the broader sense-Ought we to attain or maintain our legal subjectivity?-is regarded on that conception as a question falling outside the realm of the strictly legal and as something a comprehensive theory of law need not systematically address. This is, in other terms, a matter to be worked out in moral and political philosophy rather than in jurisprudence. Jurisprudence focuses on the problem of the obligations that can be said arise out of our being legal subjects, but it cannot be expected to explain why one ought to be regarded that way (as a legal subject) to begin with. ${ }^{27}$ Legal obligation can in this sense be described as constitutively a conditional obligation, that is, an obligation ascribable to persons only on the condition that they are participants in the legal practice.

There are two weaknesses in the account of a conditional obligation to comply with the demands of a legal system that is put forward by the champions of the conception of law as a shared activity. In the first place, the account is severely limited; in the second place, it can be shown to be ultimately irreconcilable with the fundamental tenets of legal positivism. Let us consider these two issues in turn.

\subsection{A Limited Account}

${ }^{27}$ This should not be taken to suggest that the question 'Why ought one to enter the legal domain and be a legal subject?' is nowhere discussed by those who defend the conception of law as a shared activity. See, e.g., Shapiro, Legality, supra note 2 at 170-73. In fact, there is no assumption, on this conception, that the question is trivial or that we do in fact have an obligation to be willing participants in the practice constitutive of law. The point is rather that this cannot be understood as a legal obligation, so the question needs to be tackled through a reliance on non-legal considerations, the kind a strictly jurisprudential approach is ill-equipped to handle. 
The most severe limitation of the account of legal obligation available through the conception of law as a shared activity lies in the voluntarist nature of the account. The account applies only to those who accept the rules of the system whose underlying joint activity they participate in, and so only to those who have a commitment to that system. No such obligation can be said to arise unless we also bring into play the principles of instrumental rationality: means-end coherence, crosstemporal consistency among one's plans, consistency between one's plans and one's beliefs, and coherence between one's plans and the acts performed in execution of those plans. However, these principles cannot alone explain legal obligation. We still need an agent's commitment to the relevant joint activity, since it is only through this combination-an agent's participative willingness coupled with an espousal of rational instrumentality-that, on this account, legal obligation can be explained. ${ }^{28}$ Legal obligation in the full-blooded sense is thus constructed as essentially dependent on an agent's commitment to a joint activity.

What is especially limiting about this voluntarist account of legal obligation the restriction on the class of legal participants. Only those individuals who control the levers of legal power or who have an active role in maintaining the legal system can be considered participants in the shared activity constituting the law. ${ }^{29}$ As a matter of fact, it is not clear who exactly is understood to be a participant in this circle of individuals. ${ }^{30}$ It may well be that the circle is not so closed as to encompass only the constitutional framers and maintainers and that it also includes legal officials at large. That is, legal participants may well include not only those who originally designed the system-and, thereafter, those responsible for interpreting the basic constitutional provisions and modifying the constitution when needed-but also those responsible for enacting new norms in accordance with the constitutional architecture (typically, the legislators) and those entrusted with applying the rules (law-enforcement and administrative officials). However, this is still a limited group of individuals not inclusive of the bulk of the population, the citizens at large, for whom the existence of a legal system is a fact of life.

The legal system is something over which citizens have little (if any) control, nor do they have much knowledge of its inner workings and activities. Therefore, citizens cannot be presumed to have any deep commitment to it. That is precisely because, on

\footnotetext{
${ }^{28}$ See Michael Bratman, "Taking Plans Seriously” in Elijah Millgram, ed, Varieties of Practical Reasoning (Cambridge: MIT Press, 2001) 203 at 204-19.

${ }^{29}$ This feature of the account finds its roots in Hart's jurisprudence. See especially Hart, supra note 2 at 110-17. See Coleman, Practice, supra note 2 at 96-100; Kutz, "Community", supra note 2 at 442-69; Shapiro, "Reason", supra note 2 at 417-19. ${ }^{30}$ See Matthew Noah Smith, "The Law as a Social Practice: Are Shared Activities at the Foundations of Law?” (2006) 12:3 Legal Theory 265. See generally Giorgio Pino, “' 'What's the Plan?': On Interpretation and Meta-interpretation in Scott Shapiro's Legality" in Damiano Canale \& Giovanni Tuzet, eds, The Planning Theory of Law: A Critical Reading (Dordrecht: Kluwer, 2013) 187.
} 
the conception of law as a shared activity, citizens are understood not as agents taking part in the legal enterprise but as beneficiaries. Therefore, most of the individuals law is concerned with do not fulfil what, on the conception of law as a shared activity, is argued to be the primary condition for a binding obligation to arise in connection with a shared activity, namely, an individual commitment to this activity. Nor can these individuals be expected to have such a commitment, because under the principles of instrumental rationality invoked by the conception of law as a shared activity, one can only be expected (and rationally required) to act consistently with a framework one has either had an active role in shaping or has otherwise accepted. This follows from a view of agency as autonomous rationality (the view espoused by the conception of law as a shared activity), on which we cannot expect others to comply with a scheme they have not had any role in designing. Even if we have those individuals' best interests in mind in designing the system, this is still not a basis on which to hold them bound to any provisions issued in accordance with the rules the system is governed by, for that would be tantamount to a violation of their individual autonomy. $^{31}$

So, on the principle of instrumental rationality invoked by the conception of law as a shared activity, legal obligation can be said to apply only to legal officials. It cannot be extended to anyone else, that is, to the vast majority of those who stand to be deeply affected by the existence of a legal system. Indeed, these people-the ordinary citizens-are not directly involved in shaping the shared activity lying at the foundation of law. So they cannot be said to come under an obligation to comply with any of the rules framed through such an activity. To conclude, obligation in the fullblooded sense does not (on this conception) apply to everyone: it applies only to legal officials (a small subset of all citizens). Accordingly, the conception is incomplete.

\subsection{Still Legal Positivism?}

Aside from being incomplete, the explanation of full-blooded legal obligation offered by the conception of law as a shared activity sits uncomfortably with the positivist paradigm. This is because, as I will argue, the shared activities from which obligations are derived cannot be reduced to social facts: they instead embody moral considerations, or at least moral considerations are involved in extracting obligations from those facts. This is ultimately irreconcilable with the social-fact thesis essential to legal positivism. So in this section I will show that (a) obligations associated with joint activities are moral obligations, and that (b) if we construct legal obligations as moral obligations, then we have to let go of the positivist social-fact thesis.

\section{(a) Joint Activities qua Sources of Moral Obligations}

\footnotetext{
${ }^{31}$ See generally in Bruno Celano, "What Can Plans Do for Legal Theory?" in Canale \& Tuzet, ibid.
} 
The obligations associated with a shared activity may well have a social basis-that is, they may owe their existence to the existence of a social practice-but this does not mean that such obligations are thereby exhaustively explained (by pointing out their social basis), or that they therefore have no moral value, or that whatever moral value they have only plays a marginal role in explaining their nature. To be sure, it does make sense to construct these obligations as socially based. It would be arbitrary to deny the social basis of an obligation that comes into being through a collective activity one participates in: an obligation to contribute to an enterprise one shares with others must to some extent be valid and binding for that very reason. That is, such obligation must owe its force in part to the fact that the enterprise in question engages a group of participants, and that these participants are interested in pursuing the same enterprise. What is more, it is tempting to conclude that because one's participation in a collective practice and the existence of a shared activity are both social facts, then so must be the ensuing obligation. But it does not follow from these factual premisesfrom the fact that a joint enterprise exists, coupled with the fact that an agent supports the enterprise and participates in it-that one has an obligation to do one's fair share in that enterprise (hence no free riding). Even when an activity has the endorsement of a participating agent, it is still not a sufficient basis on which to ground an obligation of the agent to satisfy the demands issuing from that shared activity. To this end we need to bring moral principles into.

The moral character of obligations arising in connection with joint activities can be said to derive from the meaning ascribed to the distinctive features of a collective practice and in particular from the mutual expectations that people come to form as participants in such a practice. When we take part in a joint activity, we come to rely on everyone's contribution to the enterprise itself, and this mutual reliance means that we can expect people to do their part or to act in accordance with what the practice requires. The relationships so structured thus bring into being a network of mutual reliance and expectations that not only distinguishes joint activities from other sorts of activities but also constitutes a necessary condition, and the ultimate source, of the obligations a collective enterprise may give rise to.

This means that there is no obligation to contribute to an existing social practice just because that practice exists and you have decided to conform to it. Rather, this obligation comes about primarily because, by joining the practice, you have led others to count on your contribution, this by giving everyone else an assurance (however implicit it may be) that you will do the things required by the practice. This idea can be arrived at as well by noting that it is morally objectionable to go back and renege on an assurance you have previously given, even if it is only an implicit assurance. One should also emphasise in this context that the requirements (obligations) the practice brings into being are constitutive of the practice: the practice would morph into something else without them, nor would they exist without the practice itself. But this does not mean that those obligations are just based on the social fact of the practice's existence. They rather come into being through (a) the moral principle prescribing you to honour the expectations you have led others to have in regard to your own behaviour and commitment to the practice, in combination with (b) the fact 
that by participating in a given joint activity you have justified others in having those expectations about you (which expectations can therefore justifiably be relied on). ${ }^{32}$

There is another way, too, in which morality figures into an explanation of the obligations associated with the existence of joint activities. Even on a voluntarist approach to obligation it is acknowledged that we cannot rely solely on the fact of acceptance-the fact that those who participate in a joint activity do so because they endorse the activity-to explain what it takes for such an activity to give rise to obligations. In other words, endorsement is a necessary but not a sufficient condition for an activity to bind its participants to an ensuing range of obligations. A shared activity may be fully and broadly endorsed, and still it will not generate any practically rational requirement if there is something morally objectionable about it. ${ }^{33}$ Therefore, it takes a combination of conditions for a collective practice to be a source of full-blooded obligations: there needs to be $(i)$ some configuration of social facts, namely, the existence of a joint activity that you are committed to, coupled with (ii) compliance with some moral standard in which the activity may be determined to be morally permissible. From this it follows that not every joint activity enlisting the commitment of its participants as a matter of social fact thereby generates obligations for those persons. Only those activities that are both factually endorsed and morally acceptable constitute genuine sources of full-blooded obligation. And the same goes for law when construed as such a practice: no genuine requirements can issue from law unless this practice, aside from having the commitment of those who participate in it (the legal subjects), can also on the whole be regarded as morally permissible. In summary, the obligations associated with a shared activity are conditional not only on social facts (on the existence and endorsement of the activity itself but also on moral considerations, that is, on whether the activity is seen correctly to comport with a morally sound principle.

There are two related consequences. First, even if law is conceived as a shared activity, this does not mean that the obligations grounded in that activity are independent of moral considerations. Quite the contrary: legal obligations, to the

32 See also Neil MacCormick, "Voluntary Obligations and Normative Powers I" (1972) 46 Proc Aristotelian Society Supp 59; Thomas Scanlon, "Promises and Practices" (1990) 19:3 Phil \& Pub Affairs 199; Michael Bratman, Faces of Intention (Cambridge: Cambridge University Press, 1992) at 135-40; Facundo M Alonso, "Shared Intention, Reliance, and Interpersonal Obligations" (2009) 119:3 Ethics 444. ${ }^{33}$ See John Rawls, Collected Papers (Cambridge, Mass.: Harvard University Press, 1999) at 121-23; John Simmons, Moral Principles and Political Obligations

(Princeton: Princeton University Press, 1979) at 109-04; Bratman, supra note 32 at 132-35. Compare David Edmonds, "Ronald Dworkin on the Unity of Value" (9 March 2012) (interview), online: Philosophy Bites $<$ http://philosophybites.com/2012/03/ ronald-dworkin-on-the-unity-of-value.html > (Dworkin's view, in regard to political institutions, that 'consensus is not indispensable; it is in many ways desirable, but consensus around the wrong idea would be worthless). 
extent that they are said to find their basis in a collective practice, are also moral obligations. Second, if we are to judge whether a legal obligation exists, we have to make morally relevant considerations, thereby engaging in moral reasoning. For, if it is a moral feature of the relevant underlying activity that ultimately determines whether or not that activity can give rise to legal obligations, it takes a moral argument to determine whether or not those obligations exist and what their content is. Or, at least, there is no way to exclude such an argument, which therefore is necessary to that end.

The conception of law as a shared activity cannot separate the requirement of legal obligation from the moral sphere. We can, on this conception, explain why those who are committed to the shared activities instantiating the law should have a genuine obligation to do what the law requires, but we cannot show this to be a morally neutral obligation.

\section{(b) A Farewell to the Social-Fact Thesis}

(b) This conclusion cannot easily be reconciled with the basic tenets of legal positivism, especially (but by no means solely) the Hartian strand of legal positivism. Hart and his epigones keep legal obligation and moral obligation neatly separated, in that legal obligation is conceived as a socially grounded requirement whose basis is independent of morality even though its contents can accidentally replicate, or partially overlap with, the contents of certain moral standards. However, this conceptual distinction between legal obligation and moral obligation melts away in the treatment legal obligation undergoes in the context of the conception of law as a shared activity. This is significant especially in light of the fact that this conception is presented by at least some of its proponents as a coherent development of Hart's jurisprudence, as a project broadly in line with Hart's distinctive interpretation of legal positivism. ${ }^{34}$

Nor can non-Hartian positivists make the claim that legal obligation is continuous with moral obligation. For this claim stands in no easy relationship with the socialfact thesis, which is widely regarded as essential to legal positivism in general. The specific reasons for the uneasy relationship between the two tenets may not emerge with immediate evidence, especially because the social-fact thesis is generally interpreted as a view concerned with the existence of law rather than with its normativity. So it will be useful to consider these two sets of issues here.

The social-fact thesis is a claim about the criteria of legality: it tells us what counts as law in a given system. The social-fact thesis remains agnostic about the questions surrounding legal obligation, for these questions concern the normative dimension of law as distinct from its existence. However, the separation between claims about the existence of law and claims about its normative dimension can be shown to be less clear-cut than may at first sight appear. This is particularly the case if

\footnotetext{
${ }^{34}$ See, e.g., Coleman, "Incorporationism", supra note 2. (Coleman describes his project as an attempt to coherently develop Hart's jurisprudence.)
} 
we conceive the law as a practical institution, that is, as an institutional framework whose basic function consists in providing practical guidance and justification by supplying agents with specific kinds of reasons for action. It is impossible here to maintain a rigid separation between the existence and the normativity of law. The reason for it is not hard to see. If law is understood as a practical institution, then its validity cannot be determined solely on the basis of whether its legal provisions exhibit certain relevant properties whose import is just theoretical. Instead, the validity of law must also be predicated on the ability of its statements, whether in isolation or in combination with others, to guide and justify action. And one way in which law guides action, while justifying the action it calls for, is by setting forth obligations. It follows that we cannot, on this conception, go about determining which legal statements exist as valid elements of a practical institution without also considering which laws are normative as obligation-imposing demands. Only when we know which laws are both valid and obligatory can we conclude that a given legal system exists as an institution capable of shaping its addressees' deliberation on how to act.

So, even though the concept of legal validity can be distinguished from that of legal obligation-the former relating to the factual existence of law and the latter to its normativity-any attempt to push the distinction beyond what is needed for analytical clarity, by actually separating the two dimensions of law, will ultimately lead to an artificial understanding likely to obfuscate the role of law as a practical institution. This is precisely how contemporary legal positivists in the analytic tradition view the law (as a practical institution). ${ }^{35}$ This makes it impossible for them (and indeed for anyone proceeding from that understanding of law) to separate the question of which legal statements are obligatory from the question of which statements are valid, and so exist, as practical directives.

This claim, as was previously being pointed out, needs to be read in conjunction with the claim that legal obligation is ultimately inseparable from moral obligation. We just saw that, on the understanding of law as a practical institution-as a system providing practical guidance-the question of the existence of law is seen to be interdependent with that of its obligatoriness and so with that of its justification. This is because both questions-whether law exists and whether it is obligatory involve to some extent an assessment of the moral values embodied by law: neither can be settled on the basis of social facts alone. For we cannot determine whether the law exists as a practical institution without first considering whether law shapes action, and the way law does this is in part by setting forth obligations. But these obligations imposed by law cannot be understood as conceptually insulated from moral obligations. And if we accept this argument (as previously laid out), then we must also accept that we cannot establish the existence of law without also engaging in moral evaluation.

\footnotetext{
${ }^{35}$ See, e.g., Coleman, Practice, supra note 2 at 134-38; Marmor, Values, supra note 2 at 25-34; Shapiro, "Reason", supra note 2 at 437-39.
} 
This view, however, is inconsistent with the social-fact thesis. This is a thesis understood as essential to legal positivism, as is the thesis that law is ultimately a practical institution. Because these two theses have been shown to be incompatible, especially in combination with the claim that legal obligation is continuous with moral obligation, any attempt to hold them together is bound to fail. This is precisely what the conception of law as a shared activity seeks to do in framing legal obligation as a kind of obligation that is not independent of moral obligation. To that extent, hence, its coherence with the positivist tenets espoused by its advocates is undermined. ${ }^{36}$

\section{Perspectivised Legal Obligation}

As we have seen, the genuine obligations the law gives rise to on the conception of law as a shared activity are constrained by two limits. They only apply to legal officials and they require compliance with certain moral standards. But we also saw that on this conception legal obligation can be understood in a perspectival sense, too, where we are instead looking at a domain-specific requirement whose implications do not go beyond the specialised 'game' the law consists in. In this sense, legal obligation is understood as binding on every legal subject and as independent of moral considerations.

Although the introduction of perspectivised legal obligation was ingenious, I will argue that it has its own problems. The most serious of these lies in the practical irrelevance of perspectivised legal obligations. Perspectivised legal obligations are practically inert. This is not a normative account of legal obligation but a descriptive one. This is a characteristic that flows directly from the way this kind of obligation is framed, that is, as an obligation one has from a certain point of view. Any statement concerning a perspectivised obligation-a statement that one is under an obligation to do or not do something from a certain point of view-can only be a statement describing the condition or state of affairs of one who is assessing the law from that standpoint, that is, from the standpoint of a legal subject. The statement can in this sense be said to have the status of a report, a report informing us of the fact thatbarring interfering circumstances-individuals in that position view themselves as justified in taking a certain course of conduct because it is obligatory. The perspectival account of legal obligation is thus descriptive through and through. For, we are not being asked to reason about legal obligation from this perspectival sense.

\footnotetext{
${ }^{36}$ This argument also counts as (the beginning of) an indirect challenge to the position advanced by Raz, who in disagreement with Hart combines an exclusive version of legal positivism centred on the social-fact thesis with the claim that legal obligation is moral. See Raz, "Hart", supra note 2 at 123-31; Raz, Ethics, supra note 2 at 210-37. Carrying out the challenge in full would require a paper on its own, which is why I cannot discuss this point any further in this context.
} 
We are only being asked to record or acknowledge what is required of one in that position and to do so from a standpoint internal to that position. ${ }^{37}$

We can see, then, what it is that makes legal obligations in a perspectival sense practically inert. Perspectivised legal obligations cannot be said to have any meaningful connection with the 'practical ought' or to have any bearing on the question of why one ought to act in the ways law requires. This is because obligation, when it is understood through the lens of a report stating how individuals ought to view their own position, is still going to come across as obligation in a descriptive sense unless it asks those people to engage in practical reasoning about why they ought to so act from that standpoint. And an obligation in a descriptive sense is no obligation at all. It is so in name only, for it cannot be said to have any practical or normative function, and without this normative function law cannot play the actionguiding and justificatory role it is acknowledged to have. Therefore, even if we recognize that law sets up perspectivised legal obligations, this will not help us determine whether and how the law makes demands on us or gives us recommendations, confers powers on us, states reasons for action, justifies this or that action, or assesses our behaviour. On this conception, legal obligations remain external to the deliberative process aimed at determining what one ought to do. At least, as we saw, they do so for the bulk of the population. A legal system so conceived cannot shape our conduct by setting forth of obligations.

Now, this will be received as an unpalatable conclusion by anyone advocating the conception of law as a shared activity, since it is difficult to accept that conclusion and still defend the view of law as an institution that shapes the practical deliberation of all legal subjects, as opposed to just shaping the deliberation of legal officials. ${ }^{38}$ The reason why the broad ability law is recognized to have in shaping our practical deliberation cannot easily be squared with the perspectival use of legal obligation is that the setting forth of obligations is widely regarded as an essential way for the law to provide guidance (it may not be the only way, but it is certainly an essential way). An account of law's action-guiding function therefore cannot hold much interest if it fails to explain the sense in which the obligations it sets forth are genuine. The conception of law as a shared activity not only fails precisely in that respect-since its theory of perspectival obligation severs the link between the obligatoriness and the normativity of law-but it does so on the broadest scale possible, by interpreting the legal obligations that most people have under the law. For, perspectival obligations apply to individuals in a non-official capacity, the capacity in which most people, most of the time, relate to the law.

This means that the very statements through which the law sets out obligations are deprived of direct practical relevance in relation to the community at large. Only

\footnotetext{
${ }^{37}$ This is acknowledged in Shapiro, Legality, supra note 2 at 184-88. For a detailed account of this aspect of the conception of law as a shared activity, see Veronica Rodriguez-Blanco, "The Moral Puzzle of Legal Authority" in Stefano Bertea \& George Pavlakos, eds, New Essays on the Normativity of Law (Oxford, Hart 2011) 86. ${ }^{38}$ This is acknowledged in Shapiro, Legality, supra note 2 at 115.
} 
individuals acting in an official capacity have genuine guidance, in a system that shapes their behaviour by (at least in part) issuing genuine obligations. By contrast, the people as a broad group (including the officials themselves when not acting in an official capacity) may well find themselves gauging their behaviour to what the legal system requires. But it is not clear how this happens, and certainly it does not happen by virtue of their being under any genuine obligation the system attaches to them. The law's practical function-that of guiding, assessing, and justifying action-will therefore have to be fulfilled in a way that does not involve a recourse to obligation. Yet this picture runs exactly contrary to the widespread intuition that law goes hand in hand with obligations (in the genuine, or practically rational, sense of the term). It is commonly accepted that law is a system capable of generally shaping the behaviour of those under its jurisdiction and that one way it does this is by setting forth genuine obligations. Yet this is precisely the feature contradicted by the perspectival account of obligation offered by the conception of law as a shared activity, which incidentally also fails to explain how the law can set out genuine claim rights (considering that these are correlative to duties and obligations).

This inability to explain genuine rights and obligations should strike one as deeply counterintuitive. Although there is no denying that the law relies on a variety of methods in governing behaviour (this can be achieved by conferring powers, designating certain actions as permissible, and so on), it is commonly agreed that ascribing rights and imposing obligations are fundamental themes. What is more, this is widely understood to be central to the practical function of law. It is hard to see how law could possibly work as a practical institution without conferring at least some rights and setting forth at least some obligations. In fact, the use of rights and obligations can be regarded, not just as one of several ways for law to shape our modes of conduct, but as paradigmatic in this respect. Yet this straightforward intuition finds no recognition in the theoretical framework provided by the conception of law as a shared activity. This counterintuitive aspect of the theory is in itself a problem if we consider that the theory is cast within the paradigm of analytical jurisprudence and that in this paradigm a prominent role is recognized for ordinary intuitions and common assumptions. ${ }^{39}$

By the same token, the conception of law as a shared activity denies the proposition that most of us can or should regard moral obligations and legal obligations as demands that can and will occasionally come into conflict. Any such conflict is explained away as merely apparent by reiterating what on the conception itself is understood to be a basic feature of legal obligation. Which is to say that, in contrast to moral obligation-recognized to be genuine obligation, and therefore capable of guiding and justifying conduct-legal obligation cannot serve any such function, at least not for the bulk of the population. So, apart from legal officials, no legal addressee can be said to be under two practical pressures pulling in opposite directions, that of morality and that of law. Moral obligations and legal obligations are mistakenly understood to pertain to two different spheres of human experience: moral

\footnotetext{
${ }^{39}$ See Shapiro, Legality, supra note 2.
} 
requirements are authentically practical; legal requirements are by contrast merely perspectivised. Therefore, the two cannot really intersect, let alone clash: no real conflict can arise between them. On one side is the practical sphere, that of moral obligation; on the other is the theoretical sphere, to which the conception of law as a shared activity confines legal obligation (at least in relation to non-officials). Because they are different in scope, the norms of law and morality cannot in any way overlap, and so any appearance of conflict between the two is just that, an illusion-one that will go away once we realize that we are not looking at conflicting demands within the same sphere but are switching between different (heterogeneous) spheres. On this conception a dilemma widely considered central to our practical existence and commonly perceived as real is instead made out to be illusory. This conclusion is less than intuitively appealing.

\section{Conclusion}

My main concern in this article has been to point out some significant shortcomings of the account of legal obligation offered by the conception of law as a shared activity. As the name suggests, the core of this conception lies in the idea of construing a legal system as what is built and maintained through a shared activity, as that which a group does when acting together in pursuit of some common goal. Through this lens the concept of a legal obligation is analysed as a requirement arising out of one's participation in a shared activity or as that which becomes mandatory by virtue of such participation. We saw that these requirements can be of two sorts. We have full-blooded legal obligation, carrying practically rational force (by virtue of its purporting to guide and genuinely justify conduct) and accordingly liable to come into competition with other sources of practical guidance. And we have legal obligation in a perspectival sense, which contrary to full-blooded legal obligation is not a practical notion but a theoretical one. Its purpose is not to engage with us in practical reasoning, but simply to state, or describe, what we ought to do if we should take the perspective of individuals subject to the jurisdiction of the legal system.

This is a bipartite account of legal obligation. This structural feature makes the whole account disjointed, giving it a lack of unity from which stem three main problems: its limited scope, its failure to recognize the moral features of obligation when made to arise out of law as a shared activity, and its failure to illustrate the sense in which law is widely recognized to be a practical institution.

So if law is a shared activity, and if genuine obligations can issue from this activity only for those who actively engage in it, then these obligations exclusively apply to legal officials, the people who participate in making, administering, and interpreting the law. Everyone else, the citizenry at large, is bound to the practice or system only in a perspectival sense. But this is not a sense that one can find satisfactory in a practical inquiry aimed at understanding, not what it is that we do as legal addressees, but why we should act that way.

The attraction of this account of obligation (perspectival as well as full-blooded) lies in its promise to extract requirements (obligations) in a value-neutral way by 
grounding them in social facts, that is, in the existence of a social practice (here, the shared activity argued to be constitutive of law). This is, after all, the whole point of a legal-positivist account of obligation. But the idea that you can take a social fact and squeeze out of it something like an obligation is illusory, since obligations (such as they are relevant in a philosophical inquiry into the law) are to be understood as practical requirements, and not simply as a function of social necessity or circumstance. We cannot just point out that something is a joint activity, and that people willingly participate or engage in it, to show that these individuals are obligated to do what the activity requires. True, a shared activity does seem to provide a sensible context in which to locate the emergence of legal obligations, but this emergence is not self-generating. If agents engaged in a joint activity have obligations, it is because they lead others to reasonably believe that they will do their part in this activity and that these expectations we come to rely on in relating to others cannot arbitrarily be frustrated. This is a moral principle, not just a social fact, and it shows how difficult it is to reconcile obligation as a practical notion with the socialfact thesis as a fundamental tenet of legal positivism.

Finally, this overall reluctance to recognize the moral aspect of legal obligation, coupled with the emphasis on its theoretical aspect, is conducive to the third basic flaw of the account, namely, its failure to make sense of law as a practical institution and, consequently, of legal obligation as a practical concept. In other words, the two features just mentioned-the attempt to ground legal obligation in social facts and the notion of perspectival obligation-conspire to yield a conception ill-equipped to shed light on the widespread intuition that law can guide and justify action by giving its addressees reasons for acting as the law requires, that is, for the obligations the law sets forth. Clearly, this is not the only way in which law guides or justifies action, but it is an important and indeed uneliminable way. By failing to shed light on it, then, the account fails to explain a feature of law (its practical nature) that few people (if any) are prepared to dismiss.

In summary, as much as it may make perfect sense to think about legal obligation by looking at the concept in its proper setting-that of the social practices out of which legal obligations arise-it seems that one simply cannot fit within the same framework two accounts of legal obligation conceived in light of two inherently different paradigms, a practical one and a theoretical one. This is not to say that we cannot legitimately pick out two different aspects of legal obligation (the one practical and the other theoretical). But if we try to mash them together or press the theoretical account into service to do the job of the practical one, then it seems we will inevitably run into the kind of contradictions I have illustrated, which I believe bog down the account of obligation offered by the conception of law as a shared activity. 